\title{
PLANT COMMUNITY AND RARE OR EXOTIC SPECIES DISTRIBUTION AND DYNAMICS IN CEDAR BREAKS NATIONAL MONUMENT
}

\author{
David W. Roberts and Catherine Jean \\ Department of Forest Resources \\ and Ecology Center \\ Utah State University \\ Logan
}

\section{objectives}

This research program incorporates four primary objectives: (1) develop a comprehensive vegetation classification for Cedar Breaks National Monument, and to map the current and potential vegetation for the monument; (2) develop a vital attributes succession model which depicts the successional development and disturbance response of plant communities in Cedar Breaks; (3) map the distribution of rare or exotic species in the monument, specifying the habitats and plant communities in which these plants occur; and (4) identify and map the distribution of undisturbed plant communities to serve as baseline reference areas.

\section{Methods}

The vegetation classification used in this study employs an existing forest habitat type (potential vegetation) classification for the forests in central and southern Utah (Youngblood and Mauk 1985). Within each habitat type, successional community types have been specified following the guidelines of steele (1984). This successional community classification classifies forest communities by specifying the least shade tolerant species present and the dominant species as a binomial. Non-forest communities are being classified according to a site specific classification developed following the guidelines of Pfister and Arno (1980).

Vegetation maps are being prepared following a two-step procedure outlined by Roberts and Cooper (1989). During collection of plot data for community description, local areas surrounding the plot are mapped in the field. These ground truth data are then employed in a classification tree predictive model developed using CART (Breiman et al. 1984). The model takes the form of a dichotomous key which is used to predict vegetation type in unsampled areas. 
The vital attributes model is being developed following the guidelines of Roberts and Morgan (1989), as previously employed in Bryce Canyon National Park. Tree species are defined by a short set of autecological characteristics which are then used in a stochastic simulation model to predict community development and disturbance response.

Rare and exotic species distributions are being determined using a two-step process. Observations of exotic species during community sampling are noted and mapped. Subsequently, transects in the observed and similar areas are employed to attempt to determine the limits of distribution.

Undisturbed communities have been identified by sampling during the course of general vegetation sampling, and by tentative identification on aerial photographs followed by field examination.

\section{$\underline{\text { Results }}$}

We have sampled 160 plant communities within Cedar Breaks for development of the vegetation classification and mapping. We have identified five forest series for a total of 18 forest habitat types. Within these habitat types, 24 successional community types are present. Non forest vegetation has been sampled and tentatively classified into five habitat types. No successional community types have been identified within non-forest habitat types.

Extensive ground-truth data surrounding the 160 sample plots have allowed mapping significant areas within the monument. Preliminary classification trees have been developed for extrapolative mapping; these trees are being updated to reflect new data. Multivariate analysis of the habitat type distribution indicates an extremely strong effect of elevation, followed by incident radiation.

The vital attributes succession model is completed for the forest communities, although parameter estimation for some forest habitat types is not yet complete.

A total of 20 rare or exotic species have been identified within Cedar Breaks, including 16 candidate species for listing as threatened or endangered. Population status reports for most of these species have been prepared. The distribution of exotic species was also determined. 
The location and distribution of undisturbed plant communities has been marked on USGS topographic maps, along with notes about the characteristics of these communities.

\section{Literature Cited}

Breiman, L., J.H. Freidman, R.A. Olshen and C.J. Stone. 1984. Classification and regression trees. Wadsworth International Group. Belmont, CA.

Pfister, R.D, and S.F. Arno. 1980. Classifying forest habitat types based on potential vegetation. For. Sci. $26: 52-70$.

Roberts, D.W., and P. Morgan. 1989. Classification and models of succession. Pages 49-53 IN: D. Ferguson, P. Morgan and F.D. Johnson (eds.). Proceedings Land classsifications based on vegetation: Applications for land managers. USDA For. Serv. Intermt. Res. Stn. Gen. Tech. Rep. INT-257. Ogden, Utah.

Roberts, D.W. and S.V. Cooper. 1989. Concepts and techniques of vegetation mapping. Pages 90-96 IN: D. Ferguson, P. Morgan and F.D. Johnson (eds.). Proceedings Land classsifications based on vegetation: Applications for land managers. USDA For. Serv. Intermt. Res. Stn. Gen. Tech. Rep. INT-257. Ogden, Utah.

Steele, R. 1984. An approach to classifying seral vegetation within habitat types. Northwest Sci. 58:29-39.

Youngblood, A.P. and R.L. Mauk. 1985. Coniferous forest habitat types of central and southern Utah. USDA Forest Service Intermt. Res. Stn. Gen. Tech. Rep. INT-187. ogden, Utah. 